\title{
Mocking the just God? A theological critique of President Mnangagwa's use of the name of God to justify his rule in Zimbabwe
}

\begin{abstract}
Authors:
Suspicion Mudzanire ${ }^{1}$ (c)

Collium Banda ${ }^{2}$ (1)

Affiliations:

${ }^{1}$ Department of Practical Theology and Missiology, Faculty of Theology, Stellenbosch University, Stellenbosch, South Africa

${ }^{2}$ Unit for Reformational Theology and the Development of the South African Society, Faculty of Theology, North-West University, Potchefstroom, South Africa
\end{abstract}

Corresponding author: Suspicion Mudzanire, pastorsuspicion@gmail.com

Dates:

Received: 05 Feb. 2021 Accepted: 02 Sept. 2021

Published: 12 Oct. 2021

How to cite this article: Mudzanire, S. \& Banda, C., 2021, 'Mocking the just God? A theological critique of President Mnangagwa's use of the name of God to justify his rule in Zimbabwe', Verbum et Ecclesia 42(1), a2218. https://doi. org/10.4102/ve.v42i1.2218

\section{Copyright:}

(c) 2021. The Authors. Licensee: AOSIS. This work is licensed under the Creative Commons Attribution License.

Read online:

Scan this $Q R$ code with your smart phone or mobile device to read online.
Zimbabwe's President Emmerson Mnangagwa justified his unconstitutional ascendency to power after a military coup that dethroned former President Robert Mugabe in 2017 by claiming that 'the voice of the people is the voice of God'. He repeated the claim in 2018 when Nelson Chamisa refused to recognise him as the legitimately elected president of the country after accusing him of rigging the 2018 elections. Mnangagwa's use of God's name to authenticate his rule raises the question: as one of the foundational attributes of God is justice, what does it mean for political leaders openly claiming to be ordained into office by him? This leads to a further question: Has Mnangagwa's rule satisfied the demands that come with claiming to be ordained by God to rule, and what should be the church's response towards Mnangagwa's rule in view of God's justice? This article uses God's attribute of justice to critically evaluate Mnangagwa's claim that 'the voice of the people is the voice of God'. The claim is described and placed within Mnangagwa's claims and insinuations to be a Christian. His current rule, which is characterised by violent repression and corruption is examined and evaluated. God's attribute of justice is presented and highlighted in how it challenges Mnangagwa to reform his rule to align it with God's nature of justice.

Intradisciplinary and/or interdisciplinary implications: The article combines insights from religion and politics, the mission of the church in a context of political oppression and systematic theology to highlight the need for the Zimbabwean churches to judge all political systems according to the adherence to God's justice. It also provides some theological tools by which churches can protect themselves from being co-opted by unjust and oppressive regimes that violate God's justice.

Keywords: justice; democracy; Mnangagwa; coup in Zimbabwe; repression; church and politics.

\section{Introduction}

Religion, particularly Christianity, played a significant role in Emmerson Mnangagwa's rise to the Zimbabwean presidency after a citizens' backed military coup dethroned the former and now late President Robert Mugabe who ruled Zimbabwe for 37 years. Mnangagwa (2017a) ascended to the seat of power by claiming that 'the voice of the people is the voice of God'. Ironically, the claim to be chosen and ordained by God to rule Zimbabwe was also a major strategy Mugabe used to entrench his 37-year rule. Similarly, the main opposition leader Nelson Chamisa, of the Movement for Democratic Change Alliance (MDCA), also an ordained pastor in the Apostolic Faith Mission in Zimbabwe, naturally uses religion to challenge Mnangagwa and his Zimbabwe African National Union-Patriotic Front (ZANU-PF) party. In the 2018 election, Chamisa contested the country's presidency against Mnangagwa by using the slogan '\#Godisinit' and his election campaign material included various Christian symbols such as a recorded prayer (263Chat 2018; Moyo 2018), and calling on citizens to fast and hold prayer vigils for the defeat of the ruling ZANU-PF (Ndlovu 2018). This shows that, although Zimbabwe is a constitutional secular democracy and a plural religious society without a particular religion aligned to the state, ${ }_{1}^{1}$ Christianity dominates the political space, resulting in a political discourse that is often laced with biblical imagery including the idea of the president as chosen and ordained by God to rule the country. ${ }^{2}$ Gunda (2015:24-25)

1.The secular and multi-religious aspects of Zimbabwe are often challenged by some Christian leaders such as: Andrew Wutawunashe (Shumba 2014) who called for Zimbabwe to be declared a Christian country and preached that Robert Mugabe was chosen and ordained by God to rule the country.

2.The use of religious language to authenticate leaders' political authority also exists in African Traditional Religions (ATR). A firm belief in ATR is that political leaders are appointed by the ancestors, the rightful owners of the land and people, to rule on their behalf (Taringa 2006:195-196). Although ATR commands a powerful influence in Zimbabwean national politics, this article, however, critiques Mnangagwa's claim to be ordained by God to rule Zimbabwe from a Christian perspective. This is based on an understanding that Mnangagwa is making his claims to be God ordained from a Christian perspective. 
described this widespread use of biblically derived symbols in the Zimbabwean political space as the 'biblification' of the public space.

Gunda's theoretical framework of 'biblification of the public space' (Gunda 2015) is used in this article to theologically critique Mnangagwa's use of God's name to validate his reign that initially started after the military coup, and was entrenched after winning the disputed 2018 elections.

A question that arises from Mnangagwa's claim of divine appointment concerns the character of God who ordains leaders and what it means for leaders to be ordained by him. Therefore, the main research question answered in this article is: as one of the foundational attributes of God is justice, what does it mean for political leaders to openly claim to be ordained into office by him? This leads to a further question: does Mnangagwa's rule meet the demands that come with being ordained by God to rule, and what should be the church's response towards Mnangagwa's rule in view of God's justice? In the ultimate analysis, the research question critiques the nature of the biblification of the Zimbabwean political space, namely whether the Bible is used liberatingly or oppressively, to constructively foster a just society, or destructively to entrench oppression? Drawing from Gunda's notion of biblification of the Zimbabwean political space, we argue that Mnangagwa's claim 'the voice of the people is the voice of God' is an oppressive biblification of the political space that ought to be challenged by, among other factors, the justice of God.

To answer these questions, this article explores Mnangagwa's understanding of being chosen by God to lead Zimbabwe. It further examines some Christian elements in Mnangagwa's religiosity that indicate that he holds to a Christian view of God. The subsequent section describes how despite his claim to be ordained by God to rule Zimbabwe, Mnangagwa's reign is oppressive and ruthless in ways that contradict God's justice. It is then followed by highlighting how Mnangagwa's government has co-opted some churches into its oppressive system to promote it among the people. The article ends by examining how God's justice demands Mnangagwa to authenticate his claim to be God-ordained by exercising just rule over his nation. Unless otherwise used to refer to a specific denomination, the word church is used in this article to refer to the general body of Christian believers.

\section{Mnangagwa's expression of being chosen by God to lead Zimbabwe}

The element of the biblification of the political space in Zimbabwe was shown by Emmerson Mnangagwa's bold assertion that God had chosen him to succeed Robert Mugabe as the country's president. Mnangagwa asserted this in his speech delivered to his supporters immediately after Mugabe announced his resignation as the president. The sequence of events leading to Mnangagwa's claim to be chosen by God is as follows. On 06 November 2017, Mugabe dismissed Mnangagwa from the post of vice president of the country after a series of accusations of attempting to topple him from power (Machivenyika 2017a). The ZANU-PF followed the suit by expelling Mnangagwa from the party (Machivenyika $2017 \mathrm{~b}$ ). After his dismissal, Mnangagwa immediately fled the country (BBC News 2017b). Meanwhile, on 21 November 2017, Mugabe announced his resignation as the president of Zimbabwe following days of massive national protest against him, and this was after the army had rolled armoured tanks and posted soldiers in strategic places around the capital in Harare, isolating and confining him at his house (BBC News 2017a). On 22 November 2017, Mnangagwa returned to Zimbabwe and triumphantly addressed a throng of ZANUPF supporters at the party's headquarters in Harare (Share \& Mugabe 2017). According to The Herald reporters (Share and Mugabe 2017), Mnangagwa told the crowd:

I think you have heard or read my letter which I sent to the President asking the President saying Mr President the people have spoken (sic.). (n.p)

While in exile, Mnangagwa had written a letter to Mugabe, released to the news media on 08 November 2017, telling Mugabe that the people no longer wanted him and he must honour the people's wishes and vacate office (News24 2017). Mnangagwa rejected his sacking by Mugabe and his expulsion from ZANU-PF, stating that it would actually be Mugabe himself and his supporters who would soon leave the party (News24 2017). He publically rejected Mugabe's efforts for a peaceful reconciliation citing safety concerns over his life (Mnangagwa 2017a). Proclaiming his 'voice of the people, the voice of God' mantra, Mnangagwa (2017a) stated:

The people of Zimbabwe have clearly spoken on this matter. To me the voice of the people is the voice of God and their lack of trust and confidence in the leadership of President Mugabe has been expressed. (Authors' own emphasis. [n.p.])

Mnangagwa further stated that he had learnt 'the voice of the people, the voice of God' framework from Mugabe his former leader and mentor. For as he stated it (Mnangagwa 2017a):

His Excellency, Cde Robert Gabriel Mugabe has always said that if the people don't want him he will leave office, now that they have spoken he must now ACCEPT the will of the people and resign. (Capital letters, original. [n.p.])

When Mnangangwa returned to Zimbabwe from exile a day after Mugabe had announced his resignation, he repeated his framework of the voice of the people as the voice of God in his words directed to Mugabe (Share \& Mugabe 2017):

You yourself said if the people say I must step down you shall comply. This is the time to comply because the voice of the people is the voice of God. (n.p.)

In these words, Mnangagwa reminded Mugabe of the words he commonly used to refute critics who called him to end his lengthy rule in Zimbabwe. Mugabe often rejected criticism of despotism by saying that he remained in power because Zimbabweans had voted for him, which meant that he was ruling with the consent of his people (Chinaka 2017). 
Mugabe had on many occasions promised to honour the voice of the people if they no longer wanted him and voted him out of office. For example, towards the 2008 elections, he reportedly stated, 'If you lose an election and are rejected by the people, it is time to leave politics' (Winter 2017). He, however, changed his stance when he came second to the opposition leader Morgan Tsvangirai of the Movement for Democratic Change (MDC) and a re-run of the presidential election had to be performed because Tsvangirai had not garnered the $50 \%$ threshold to be declared the winner. Turning against his earlier promise, Mugabe belligerently avowed: 'MDC was never allowed to rule this country - never ever. Only God, who appointed me, will remove me - not the MDC, not the British' (News24 2008). Although Mugabe never qualified what God's way of removing him from power would look like, his statement showed that election was not one of them. Perhaps, he meant when his own ZANU-PF decided that they no longer wanted him as their leader, in which case Mnangagwa's letter was on point.

Mnangagwa threw the rule book back to Mugabe and asked him to comply with the people's publicly demonstrated dislike of him in the nationwide protests against him. For Mnangagwa, this citizen's rejection was actually God speaking against Mugabe. By default, this was God's voice to Mnangagwa to assume office. Although Mnangagwa has continued to express his awe and loyalty to Mugabe as a mentor and father figure (Mnangagwa 2017b), he effectively used the name of God to delegitimise him. Invariably, Mnangagwa declared himself God's chosen leader for Zimbabwe. It seems that the claims by former leader Mugabe that he was divinely appointed to lead Zimbabwe, and could therefore only be removed by God from power, caused those who unconstitutionally dethroned him 'to justify their actions by insinuating that their actions were inspired by God' (Mbofana 2018). In that sense, appeals to divine selection by politicians are a means of justifying their unconstitutional takeover of power. Thus, to gain political and moral legitimacy, Mnangagwa employed God's name to sanitise and project himself as a servant of God seeking God's mission to govern his people. Politicians make reference to God in their political rhetoric to indicate God as the ultimate authority in their political ambitions and missions. This makes it look as if they are representing God and their activities are part of God's mission.

It is not so clear what Mnangagwa meant by the voice of the people is the voice of God. It could mean the seriousness with which he treats being chosen by the people and mandated to rule the country. It could also mean that his election by the people is an actual divine act of God, which means that anyone who resists and rejects Mnangagwa resists and rejects God, for the voice of the people is the actual voice of God. This would also mean that it is an act of disobeying God for Mnangagwa to not take up leadership as the president of the country. This later view seems to express how Mnangagwa is portraying himself and this is how some people understand him. For example, Chimininge (2019:43) said for Mnangagwa to win support from the locals he appealed to God using religious language'. He projected himself as the one whom God had ordained and handed the sceptre and the throne.

\section{Some indications of Christian ideas in Mnangagwa's view of God}

An ensuing question concerns the nature of the deity in Mnangagwa's claim for divine ordination to the public office. Who is the deity in Mnangagwa's thought? Chimininge (2019:47) said that the God in Mnangagwa's speeches is ambiguous and may not be necessarily the God of the Bible. However, a careful listening to Mnangagwa's references to God will disagree with Chimininge's position, by highlighting some shades of belief in the Christian God. Firstly, by his own public admission, Mnangagwa is a member of the Methodist Church where his wife, Auxillia, attends (Ruwende 2017). He publicly declared his Christian faith and membership in the Methodist Church at a Christmas Eve church service at the Mabelreign Methodist Church in Harare (Ruwende 2017). Mnangagwa was quoted in news addressing worshipers at the Methodist Church declaring (Ruwende 2017):

I am a congregant of this church... We have come to this church which I grew up in. Most of you were not born yet in the 1940s. I attended this church before we migrated to Zambia which was still called Northern Rhodesia. We went to Kafue Mission, which is also a Methodist institution but I later left to join the liberation struggle. When we came back from war I attended church services here briefly while staying in Tynwald but I stopped again. (n.p.)

He added that his wife, Auxillia, who often appears in public interdenominational church gatherings adorning church regalia associated with the Methodist Church, insists that they should go to church and congregate with other believers and had since convinced him to return to the church (Ruwende 2017). This is a good indication that Mnangagwa's references to God refer to the Christian God.

A Christian belief can also be seen in Mnangagwa's various addresses in the different church gatherings he has attended. For instance, in January 2020, Mnangagwa addressed an international gathering of Zimbabwe Assemblies of God Africa (ZAOGA) pastors in Harare. He reportedly pointed out that churches, schools, hospitals and universities bring people together from diverse family backgrounds to form 'a family united by the blood, love and grace of our Lord Jesus Christ' (Madzimure 2020). In March 2019, Mnangagwa addressed a memorial church service to remember people who perished in the deadly Cyclone Idai and reportedly told the gathering (Chikwati \& Munyoro 2019):

Job lost all his children and wealth, but he never turned away from God. We should accept this, although it is difficult, even for me. Sometimes we ask God why he allows such things to happen and also if he still exists. We cannot direct God, but we just accept what he has done. Let us pray and seek God when we still can, as disaster can come anytime and in different forms. We are all sinners and we should all go to Jesus when we are still alive. (n.p.) 
His words show a biblically informed understanding of God's sovereignty and humanity's powerlessness in controlling the events of the world. The evangelistic element in calling people to turn to Christ clearly shows his Christian view of God.

A Christian expression of the view of God is further seen in Mnangagwa's address on 19 October 2019 on National Day of Prayer organised by his wife at the State House in Harare. The president was reportedly quoted by a journalist (Garusa 2019) saying:

We are gathered here at the State House not to praise the First Family but as a supplication to God. It is only Him who can assist our nation. He says even if you are heavy laden, He will assist you. (n.p.)

The statement dispels any sinister motives on the part of his wife in hosting the pastors at his presidential residence and quotes Christ's words in Matthew 11:28-30. Mnangagwa's 2020 Easter message applied the essence of hope in the Easter celebration to the pain caused by the coronavirus and was reported saying (Taruvinga 2020):

As we commemorate the death and resurrection of our Lord and Saviour Jesus Christ, may we be reminded that we have a faithful God who is ever present even in the midst of this global threat to life as a result of COVID-19 pandemic. (n.p.)

This application of Easter to the current experiences of tragedy demonstrated a Christian understanding of God. This Christian understanding is further demonstrated by his statement:

This Easter holiday may we be further encouraged by the knowledge that Jesus Christ triumphed over death. His love is much more powerful, offering us assurance that the difficulties and challenges that threaten to overwhelm us, will be overcome. (Taruvinga 2020:n.p.)

This gives a strong indication that when Mnangagwa mentions God in his speeches, he is referring to the Christian God.

However, at other times, Mnangagwa has made controversial religious statements that may suggest a questionable understanding of God and the Bible. For example, in March 2019, he illustrated that there will always be people who criticise his programmes by saying, 'Even the Lord upstairs could not keep his house in order, he had Satan, so these things happen, but he still remains there as the creator' (Machaya 2019). Although this statement won him severe criticism, with others calling him blasphemous and others condemning him for labelling his opponents as satanic (Machaya 2019), it nonetheless indicated some awareness of biblical facts.

Still, some of his public addresses give nuances of syncretistic adhering to Shona traditional religion. This can be seen in his response to critics of his government's erection of the statue of Mbuya Nehanda, a spirit medium famous for her role in leading the earliest armed resistance against British colonial occupation of Zimbabwe. Mnangagwa rebutted the criticism by saying: 'We recognise Jesus Christ because he died for us and we are also recognising Mbuya Nehanda because she led us during the war' (Machivenyika \& Ziwira 2020:n.d.). This equating of Jesus Christ and Mbuya Nehanda, of eternal salvation and political liberation, suggests a poor understanding of the divine work of God at the cross. At other times, Mnangagwa has appeared as an adherent of Shona traditional religion such as when he said whoever dreamt a period of time when Zimbabwe was no longer ruled by ZANU-PF, that person should immediately wake up and consult his or her ancestors and ask them why they were abandoning him or her (Youtube 2018). ${ }^{3}$ Mnangagwa's statement showed the traditional belief that dreams are communication from the ancestors and he considered dreaming of Zimbabwe no longer ruled by ZANU-PF a sign of being abandoned by one's ancestors. Despite these faulty views of God, there is overwhelming evidence to conclude that the God in Mnangagwa's political discourses is the Christian God.

\section{'Voice of the people as the voice of God': Messianism or legitimation of injustice? \\ Mnangagwa's messianic use of God's name}

The above noted position that there is some compelling evidence that Mnangagwa subscribes to a Christian view of God makes it necessary to further analyse his political rhetoric uses of God's name and ultimately how he uses the Bible as the Christian canon on factual knowledge about God. Gunda's (2015:14) criticism of the biblification of the political space in Zimbabwe is the concern that religion or sacred texts such as the Bible can play the contradictory role of establishing a just society and also of aiding human exploitation and oppression. Gunda (2015:18) further stated that the colonial experience is a sordid reminder to indigenous people of the co-option of the Bible into the colonial system of exploitation and plunder. At the face value, Mnangagwa used biblification to present himself in messianic terms, as one appointed to save Zimbabweans from Mugabe's wretched tyranny. He demonstrated his messianism by announcing a people-centred mission. Addressing his supporters who came to welcome him on his return from his 16-day exile in South Africa, Mnangagwa reportedly told the crowd (Share \& Mugabe 2017):

I appeal to all genuine, patriotic Zimbabweans to come together, we work together. No one is more important than the other. We are all Zimbabweans. We want to grow our country. We want peace in our country. We want jobs, jobs, jobs! (n.p.)

By promising a new era that provided jobs to millions of unemployed young and old citizens, Mnangagwa's words sounded like a day of salvation as an answered prayer to millions of desperate citizens ravaged by tyranny and a failed economy under Mugabe's reign.

Mnangagwa (2018) followed up on his 2017 messianic promises in his 2018 inaugural address after winning the

3.Stated in Shona Manangagwa said, 'Kana ukarota nyika ino ichitongwa nemusangano usiri Zanu PF, muka ubike dorokuti hope dzabvepi idzi. Bika dorokut nemusangano usiri Zanu PF, muka ubike doro kuti hope dzabvepi idzi. Bika doro kuti

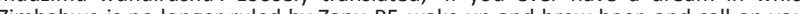
Zimbabwe is no longer ruled by Zanu-PF, wake up and brew beer, and call on your ancestral spirits and ask them where such a dream is coming from. Brew beer and entreat your ancestral spirits to not abandon you'. 
controversial elections by presenting himself as a unifier of the divided nation because of the divisions arising from the disputed polls and reportedly announced (Garusa 2019):

God says I am the one who appoints Kings and the King must know that the voice of the people is the voice of God. The leader should know that the people I am leading are God's people not my people. Some are not content with their roles in nation building and want to stray into the roles assigned to different people. My arms are stretched wide. Every political party, come, let's have a dialogue. (n.p.)

Therefore, in using God's name in his political language, Mnangagwa presented himself as the servant of God.

\section{Mnangagwa's use of God's name to legitimatise injustice}

However, despite the messianic tones in Mnangagwa's claim to be God's servant ordained to rule Zimbabwe, his claim for ordination by God has many signs of using biblification to legitimise unjust rule in the country. It is well-known that Mnangagwa was one of the Mugabe's longest trusted lieutenants, and it is widely speculated that he is one of the chief architects of the heinous crimes committed by Mugabe's government against innocent citizens, such as the genocidal slaughter of mostly Ndebele speaking people in Matabeleland and Midlands provinces in the 1980-1987 military operation known as the Gukurahundi. This means that Mnangagwa's moral standing was no better from Mugabe's dictatorial ruthlessness. Therefore, a serious concern about his use of the claim to be ordained by God to rule Zimbabwe was not accompanied by remorse for the roles he had played in aiding Mugabe's tyranny in Zimbabwe. Instead of earnest remorse, Mnangagwa offered a flimsy argument to the angry masses 'let bygones be bygones' and asked people to forgive one another for their past hurts but did not take personal responsibility for his destructive role in Zimbabwe. This means that Mnangagwa used God's name to gain moral ground in the light of serious accusations of ruthlessness against him. Chimininge (2019:50) is right in his view that Mnangagwa used religious language to gain moral authority and political recognition in the country. In other words, Mnangagwa used God's name to sanitise himself against his past tyranny, instead of changing his ways and mending broken relationships with the brutalised citizens.

A serious problem in Mnangagwa's claim to be God-ordained to rule Zimbabwe is that his rule continues to be characterised by oppression that raises questions about his claim to be appointed by God to rule the nation. Mnangagwa's messianic claims to be chosen by God to lead Zimbabwe ironically do not show a commitment to God's demand on rulers to rule with justice (2 Sm 23:3-4; Rm 13:4). That Mnangagwa can boldly claim and defend his rule as ordained by God and yet continue with the gross injustices and corruption further raises questions about his true knowledge of God. Ultimately, we are left to conclude that Mnangagwa's claims of divine ordination are a mockery of God whose foundation of authority is justice and righteousness (Ps 89:14). In many ways, Mnangagwa's touted 'Second Republic' or the 'new dispensation' is not different from Mugabe's 'old dispensation' or 'First Republic'. For example, Human Rights Watch (2020) reported that Mnangagwa's Zimbabwe is 'highly intolerant of basic rights, peaceful dissent, and free expression'. The group listed several chilling events that included murders of civilians, rape of women and various incidents of abductions, torture and beating by the state security agents and the perpetrators of these heinous crimes were never brought justice (Human Rights Watch 2020:n.p.).

Thus, Mnangagwa's Zimbabwe remained as violent and unjust as Mugabe's Zimbabwe. Disturbingly, some ordinary Zimbabweans have begun to speak favourably about the oppressive reigns of former president Robert Mugabe and the racist rule of Rhodesian Prime Minister Ian Smith as indicated by Makomborero's (2020) post on Twitter:

Black workers earned far better wages under Ian Smith's Rhodesian government than black workers are earning under Emmerson Mnangagwa's Zimbabwe government. Smith's economic responses to sanctions was industrialisation whilst [Mnangagwa's] economic response is increased corruption (n.p.).

It speaks volumes when citizens begin to miss former tyrants such as Ian Smith whose racist reign was extremely oppressive and resulted in a civil war that killed thousands of Zimbabweans. Because of these oppressive acts, Chimininge (2019:49) rightly observed that Mnangagwa's rule no longer sounds like the voice of God.

In addition to gross corruption and looting of national resources, Mnangagwa's rule has proved unable to govern efficiently by using the limited resources to boost a robust home grown economy as Smith did when Rhodesia was under United Nations approved international sanctions. The government has used the limited resources on nonessentials such as the chartering of expensive aircrafts for the president's travel and a ballooned costly cabinet of ministers. Mnangagwa's government has used the current deadly COVID-19 pandemic as an opportunity to act corruptly by stealing the funds designated to fight the pandemic and has used the lockdown implemented to curb infections as a means to brutalise dissenting voices and trample on people's freedoms (Buchanan-Clarke \& Mashingaidze 2020).

A further problem with Mnangagwa's claim to be Godordained to rule Zimbabwe is that he uses God's name to promote narrow patriotism by merging God's reign with his oppressive political system. Mnangagwa's claim to be Godordained monopolises the name of God and merges God's reign into his personal reign in a way that ultimately demonises his critics and opponents. Consequently, to oppose Mnangagwa is ultimately seen as opposing God who has ordained him into office. This seems to represent Jesus' words, 'He that is not on my side is against me, and he that does not gather with me scatters' (Lk 11:23). This also leads to narrow Christian religiosity in that a true Christian is, in the final analysis, one who supports Mnangagwa and praises him instead of opposing or criticising him. Zimbabwe's past 
oppressive regimes have also been known to use God's name to promote narrow patriotism and spirituality. Case in point, when Ian Smith announced his Unilateral Declaration of Independence in 1965, one of the reasons he gave was the defence of Christianity (Zvobgo 2005:382). Similarly, when Mugabe started expropriating farms from white farmers and gave them to landless black Zimbabweans, many ZANU-PFaligned pastors presented him as Moses sent by God to liberate Zimbabweans from white farmers who stole the African lands (Dombo 2014:146). Incidentally, the slogan '\#Godisinit' by Zimbabwe's main opposition politician Nelson Chamisa of MDCA also uses God's name to promote narrow patriotism and spirituality by suggesting that God is only on the side of Chamisa, which means that a true Christian can only vote Chamisa and not Mnangagwa, who is supposedly without God. These instances show the absurdity of the uncritical merging of God with narrow party political agendas.

Sadly, the politicians' claim to be God-ordained has led to a polarised Christian church in Zimbabwe. By listening to some church leaders' political statements, one can guess which churches are pro-Mnangagwa and which ones are pro-Chamisa. This shows that religious language that is evidently partisan, such as that which compares Mnangagwa with God the Creator while at the same time putting the opposition at par with Satan (Ndore 2019:1), is divisive and exclusionary by anathematising dissent. In Mnangagwa's Second Republic, dissenting voices act against God and can therefore be denied their human rights and be subjected to all forms of inhumane torture and treatment.

A sad reality of Mnangagwa's use of God's name to legitimise his rule in Zimbabwe is its mocking of the millions of people who have endured his oppressive and ruthless rule and wish to be saved from it. We earlier pointed out that Mnangagwa is thought to be one of the architects of the excesses of Mugabe's rule such as the genocidal atrocities in the Matabeleland and Midlands provinces that are estimated to have killed over 20000 people. Furthermore, as already noted Mnangagwa's current reign is characterised with the brutalisation of the citizens, massive corruption, ruthless silencing of the opponents and a selective application of the law that has seen criminals go scot-free because of their association with Mnangagwa, while political opponents and critics have languished in remand prisons for minor offences. Given this brazen ruthlessness, for Mnangagwa to claim to be fulfilling the voice of God, is to mock the victims who are praying to God for justice. Mnangagwa's claim to be fulfilling God's voice while perpetrating injustices on his citizens mocks the wounds of the people harmed by his rule and also mocks the God of justice to whom they are praying to give them good and just leaders. Mnangagwa's claim to be fulfilling God's voice mockingly says to the poor and hurt people waiting on God for a good and just president, that he is their answered prayer. Ultimately, the God of justice is mocked, because he is presented as siding with the evil oppressors against the poor and powerless masses.
Ultimately, the merging of God and Mnangagwa's rule commodifies God and turns the sovereign divine being into a tool that can be easily appropriated by the powerful leaders to oppress the weak members of the society. Commodification carries the idea of thingification, which is the turning into a personal private thing, of that which belongs to everyone and ought to freely benefit everyone (Banda 2019:2; Hadebe 2017:2). By Mnangagwa's claim that his oppressive and evil rule is fulfilling God's name, God is stripped of his sovereign divinity and independence, and reduced into a commodity that is used to stamp oppressive human programmes. Oppressive rulers commodify God to rob him of his authority and power to demand accountability from them. It can be stated that to a large extent, Mnangagwa's claim to be fulfilling God's name while carrying out brazen acts of injustices and corruption ultimately strips God of the authority and power to hold him accountable for his actions, because instead of aligning his rule to God's standard of justice, he turns God into a tool for perpetrating injustice and his own self-aggrandisement.

\section{The co-option of the church into Mnangagwa's oppressive system}

Although there are several church voices that have audibly opposed Mnangagwa's oppressive rule (Dzirutwe 2007; The Herald 2020), Mnangagwa's biblification of the political space in Zimbabwe has been successful because there is a large influential section of the Zimbabwean church that can be described as co-opted by the oppressive state. By the same token, there are Zimbabwean churches that can be described as co-opted by the opposition party; however, in this article, our interest is limited to those co-opted by the state. However, some church bodies such as the Zimbabwe Catholic Bishop's Conference, the Catholic Commission for Justice and Peace have maintained a prophetic critical stance towards the political situation in the country and have at times produced scathing pastoral letters invoking the wrath of the ZANU-PF government (Dzirutwe 2007; The Herald 2020). Bodies such as the Zimbabwe Council of Churches and Evangelical Fellowship of Zimbabwe generally take a guarded pastoral approach that seems aimed at avoiding annoying the government.

However, there still remains a large body of church leaders who can be classified as co-opted by Mnangagwa's government. Magaisa (2019) said that throughout the course of history, despots have never ruled alone because ' $[t]$ hey never have the capacity to achieve that feat on their own'. These despots rely on 'enablers' in the form of various individuals and groups who enable them to gain power and hold onto it (Magaisa 2019). In Mnangagwa's ascendancy to power and keeping hold of it, 'he has benefited from an assortment of enablers even though some of them try to wriggle out of responsibility that comes with their role' (Magaisa 2019). Similarly, Dube (2020:1) highlighted that enablers of Mnangagwa's regime actively ensure that he remains in power, regardless of his failures to deliver a prosperous country to the citizens, and they force him on 
people through lies, propaganda and where necessary, violence. Sadly, there are many church leaders who have actively supported Mnangagwa's regime who affirm and promote its legitimacy despite the numerous injustices associated with it. Hence, Dube (2020) spoke about 'Regime enablers and captured religious mandate in Zimbabwe'. However, this is not new, as it was the case even in Mugabe's era (Banda \& Senokoane 2009) and some of the church leaders who enabled Mugabe's regime continue to perform the same task in Mnangagwa's regime.

Many church leaders easily embraced Mnangagwa soon after the coup that brought him into power, taking over from Mugabe. For example, in March 2020, four months after Mnangagwa had come into power through a military coup, The Herald newspaper carried an article entitled 'Churches endorse $\mathrm{ED}^{\prime 4}$ and reported several influential church leaders attending a meeting with Mnangagwa and lavishing glorious praises on him. Bishop Nehemiah Mutendi, leader of the massive Zimbabwean Zion Christian Church was reported telling Mnangagwa (Share 2018):

Do not be afraid, President, we are with you. Some people say we are being ruled by soldiers, which is false. We are being led by mature people who came from the war. Those who are still in the army are not here. What is left is for us to go and tell our people on the direction to follow. (Authors' added emphasis. [n.p.])

Mutendi'sstatementlegitimisedMnangagwa'sunconstitutional takeover of power and at a time when many citizens were becoming disgruntled with his rule and the militarisation of the state. What is most worrying about the bishop's statement is the promise that followers will be directed on the direction to follow. The problem is that church leaders act in a partisan manner and use their religious power to harass their followers to submit to Mnangagwa's rule. This is a sign of being co-opted by the state for evil purposes.

There are many reasons why the biblification of the state makes it easy for some church leaders to be co-opted into the oppressive ZANU-PF system. A basic reason is the simplistic interpretation of passages such as Romans 13:1-2 and 1 Peter 2:13-17 that teach Christians to submit to governing authorities because these authorities have been established by God. Many Christians approach these texts in a simplistic manner. Yet, the apostles who wrote these very instructions also resisted the evil rulers by telling them: 'Judge for yourselves whether it is right in God's sight to obey you rather than God' (Ac 4:19) and also said, 'We must obey God rather than men' (Ac 5:29). This shows that submission to civil authorities must not be made uncritically.

Christian leaders are also co-opted by Mnangagwa out of shallow nationalism and patriotism that simplistically believes Mnangagwa's propaganda that he and his ZANUPF party are the only true custodians and defenders of Zimbabwe's liberation from colonial rule and security from
Western neo-colonialism. As many church leaders do not want to be viewed as unpatriotic citizens or enemies of the state, they willingly or forcibly get co-opted into Mnangagwa's system. This scheme of thought also merges God and Mnangagwa into one thing so that allegiance to Mnangagwa becomes the test of patriotism and a true Christian. The evidence of this is the many prayer meetings organised or sponsored by the state in which pastors and ordinary Christians are compelled to come and pray for the president and the country. This suggests that true Christians will be seen by attending state-sponsored prayer meetings.

Furthermore, over the years, ZANU-PF has developed a system of patronage that many people rely on for their economic survival and upward mobility in the damaged economy (Magaisa 2020). Zimbabwe's economy is tightly controlled by the ZANU-PF, the private business sector is very small leaving most citizens dependent on the government even for many basic business activities such as operating a stall in a public marketplace. This means that no one can afford to be on the wrong side of the ZANU-PF. Many dissenting voices have had their farms and wealth taken away from them by the ZANU-PF government. Thus, many church leaders have been trapped into Mnangagwa's patronage system for personal wealth and even land for their churches and related institutions (Magaisa 2020).

However, sometimes, church leaders allow themselves to be co-opted into Mnangagwa's system as a means of coopting him into their church and personal agendas. In this case, churches welcome Mnangagwa's expressions of being an instrument of God and use it to draw close to him to exploit him to their advantage. Sometimes, the churches' co-option of Mnangagwa is created by a fear that rivalry religions may gain a stronger influence over the state and dilute the Christian influence in the country. Therefore, there is the fear that if the Christian churches antagonise the rulers, other more cordial religions may win the government over and erode the influence of Christianity in the land. In a context of intense competition between various religions to influence the state and public opinion, the constant presentation of Mnangagwa by the media hosting pastors and being hosted by them for prayers, and even kneeling in a church to pray, sends the important message that Christianity has some notable spiritual control over the state which other religions may not have. At the same time, perceptive politicians may use the cordiality of the church leaders towards them to exploit it to their political advantage.

However, the problem of the co-option of the church into Mnangagwa's system is the loss of the power to be the salt and the light of the world. It also cripples the church's prophetic role in challenging the state's corruption and abuse of citizens. 


\section{The challenge of God's justice to Mnangagwa's use of God's name to justify his oppressive rule in Zimbabwe}

Gunda's (2015:124) remedy to the biblification of the public space is 'critical biblification' which means 'critical appropriation of the Bible' in public discourse in Zimbabwe. He adds, 'We should bid farewell to the days when people (public officials and religious leaders) would get away with careless appropriations of the Bible' (Gunda 2015:124). In view of Gunda's call, it is argued that a sound understanding of the character of God, in particular his attribute of justice, challenges Mnangagwa's use of God's name to justify his oppressive rule in Zimbabwe. The biblification that is informed by God's justice also challenges the church from uncritically endorsing Mnangagwa's rule as God-ordained. God's ordination of civil authorities is embedded in his just nature which demands that civil authorities must rule over their subjects justly.

\section{The justice of God}

The church must remind Mnangagwa to realise that one of God's foundational attributes is justice, and therefore leaders who claim to be ordained by God must have a high sense of God's justice. God is just and demands civil leaders, especially those who are aware that they have been appointed by him, to display this attribute in their rulership. In this case, Mnangagwa needs to be reminded of the words of the Queen of Sheba to King Solomon 'the Lord your God has made you king to carry out justice and righteousness' (1 Ki 10:9). Methula (2014:114) emphasised that the 'Bible is full of passages that place the call for justice in the centre of its teaching'. He added that justice is not only an important issue in all societies, but also 'it is a central theme in Christian theology' (Methula 2014:114). The Bible asserts that justice is a foundational attribute of God: 'Righteousness and justice are the foundation of your throne' (Ps 88:14). As asserted by Moses, 'all his (God's) ways are just. A faithful God who does no wrong, upright and just is he' (Dt 32:4). According to Grudem (1994:203), 'God's righteousness means that God always acts in accordance with what is right and is himself the final standard of what is right'. In the Bible, justice and righteousness are inseparably linked, for when applied to God, righteousness means that his actions are in accordance with the law that he has established, and justice means that he fairly administers his law without any favour or partiality (Erickson 1998:258, 259). Therefore, in the Bible, God condemned judges and civil authorities appointed as his representatives to deliver justice among their people for accepting bribes to make biased judgements (1 Sm 8:3; Am 5:12), because God himself is just, he expects public officials, particularly those who identify themselves with him, to follow suit and be just (Erickson 1998:259). This shows that justice is a communicable moral attribute that God expects all his people to have, particularly those in leadership. Mnangagwa should therefore be challenged to make good his claim to be ordained by God to rule Zimbabwe by being a just ruler, not the one he has shown himself to be who is unjust, corrupt and ruthless over his people.

\section{Justice as a protector and promoter of the well-being of the people}

In the Bible, justice is not only an abstract concept but also a functional one that protects and promotes life in human societies. As Proverbs 29:2 states, 'When the righteous thrive, the people rejoice; when the wicked rule, the people groan'. The rejoicing that comes when the righteous are in authority can be associated with the protection and enhancing of the well-being of the people. The groaning of the people resulting from the rule of the wicked is related to oppression and the stifling of life and progress. Commenting on this proverb, Longman (2006:501) said that the community prospers when the righteous are in control because they lead with wisdom and justice; the community moans when the wicked are in control because they make foolish decisions and exploit the people. Longman showed that justice is life-giving and life-sustaining, while wickedness brings destruction in the community.

Mnangagwa's claim to be ordained by God to rule Zimbabwe must be challenged, and it must be highlighted that God expects those who claim to be associated with him to emulate his righteousness and justice by exercising righteous and just rule that entails protecting and promoting their well-being (Am 5:15,24; Ja 2:9). The notion of justice as a protector and promoter of the well-being of the people challenges national leaders such as Mnangagwa to see the purpose of civil authority as first and foremost as being God's instrument of bringing justice and promoting the well-being of the society.

This means that the church should change how it interprets passages on civil authorities such as Romans 13:1-7. Instead of interpreting these passages in ways that sacralise and absolutise the state, they should be interpreted from the view of God's interest in justice that protects and enhances the well-being of the people. The use of Romans 13 to whip Christians into blind submission must pay attention to verse 4 of that chapter which states:

For the one in authority is God's servant for your good. But if you do wrong, be afraid, for rulers do not bear the sword for no reason. They are God's servants, agents of wrath to bring punishment on the wrongdoer. (Rm 13:4)

In their reflection of this passage, Banda and Senokoane (2009:235) amplified the fact that 'the God-intended purpose of the state is to serve God on behalf of its citizens'. Romans 13 does not licence tyranny, but reminds civil authorities that they should be instruments of justice that uphold and promote law and order. Therefore, Mnangagwa should be challenged to realise that God's intention in ordaining the office of civil authority is for those in power to serve him by maintaining justice, law and order among his people. From a biblical perspective, the authority of the state is not absolute but limited to the purpose of executing justice, preventing corruption and protecting the poor and weak in society from 
being exploited by those who are evil and the powerful. Civil authorities should be democratic and not sacralise themselves for at the end of the day they are human beings equal to all humanity and accountable to God and their people on how they exercise their power (Mi 2:1; Am 5:24).

\section{The church must fulfil its prophetic role and resist co-option into oppressive systems}

It was highlighted in the previous section that some influential church leaders have been co-opted by the state to function as its enablers (Dube 2020; Magaisa 2019). However, instead of giving credibility to an evil regime by sacralising it as God-ordained and harassing poor, powerless and suffering citizens to submit to it, church leaders must be agents of justice and resist co-option by Mnangagwa's oppressive system. The recent pastoral letter by the Zimbabwe Catholic Bishop's Conference (2020) entitled 'The March is not Ended' published on 14 August 2020 set an example by which church leaders can be agents of justice and resist being co-opted by the state. It was significant that when the Catholic Bishops received vitriolic attack from the state other church bodies such as the Zimbabwe Council of Churches and the Evangelical Fellowship of Zimbabwe, large denominations such as the Anglican Church closed ranks with the bishops to support them. However, some church leaders close to the state sided with the ruling elites and lambasted the Catholic Bishops for criticising Mnangagwa's government. This condemnation of the Catholic Bishops for a pastoral letter criticising the government injustices shows that some church leaders are often more prepared to defend ZANU-PF than stand with the oppressed and abused masses (Dube 2020:7). Instead of standing in solidarity with the oppressed poor and powerless, some church leaders stand with ZANU-PF, often because of narrow national patriotism and shallow PanAfricanism that considers criticism of liberation of movements as an act of support for white imperialism. Chingarande (2019) stated that religious leaders, such as Mutendi are guilty of serving the ruling party instead of serving the state. As Chingarande (2019) further stated, 'Instead of safeguarding the integrity of institutions, they manipulate and abuse them for the benefit of the ruling party'. To avoid co-option by the state, church leaders should avoid greed, materialism and naivety that open them to the state's machinations to seek to control them and silence their prophetic role.

\section{Conclusion}

Mnangagwa's use of God's name to authenticate his rule in Zimbabwe was evaluated by asking the question: As one of the foundational attributes of God is justice, what does it mean for political leaders openly claiming to be ordained into office by him? It was further asked, has Mnangagwa's rule satisfied the demands that come with being ordained by God to rule and what should be the church's response towards Mnangagwa's rule in view of God's justice? The article highlighted that there is a pervasive use of the Bible in Zimbabwean politics that allows politicians to pursue a systemic propaganda that fosters political repression and injustice in the country. Therefore, despite Mnangagwa's justification of his rule by claiming 'the voice of the people is the voice of God', his reign is characterised by acts of injustice and repression which violate God's nature of justice. In this respect, the use of biblical language by Mnangagwa seems to be for oppressive reasons and raises questions about his understanding of the God he claims has chosen and ordained him to rule Zimbabwe. Further, the undesirable realities advanced by his rule leave much to be desired with regard to his commitment to God and his demand for rulers to rule people justly. In view of this, Mnangagwa and his supporters should correct their view of civil authority according to God's attribute of justice, and recognise that God demands this quality from leaders, especially those who claim to worship him. The church must challenge this abuse of God's name to justify repression. Church leaders must realise that their cooption by the state to function as its enablers in oppressing the citizens is a mockery of the just God who has ordained the office of civil leadership to instil, maintain and promote justice in communities.

\section{Acknowledgements}

The authors would like to thank Dr Dambudzo Mbendana who read the final draft of the manuscript and offered helpful comments for improving it.

\section{Competing interests}

The authors declare that they have no financial or personal relationships that may have inappropriately influenced them in writing this article.

\section{Authors' contributions}

S.M. and C.B. contributed equally to this work.

\section{Ethical considerations}

This article followed all ethical standards for research without direct contact with human or animal subjects.

\section{Funding information}

This research received no specific grant from any funding agency in the public, commercial or not-for-profit sectors.

\section{Data availability}

Data sharing is not applicable to this article as no new data were created or analysed in this study.

\section{Disclaimer}

The views and opinions expressed in this article are those of the authors and do not necessarily reflect the official policy or position of any affiliated agency of the authors. 


\section{References}

263Chat, 2018, Chamisa's prayer for Zim Elections, \#263Chat, viewed 22 Novembe 2020, from, https://www.youtube.com/watch?v=bN6LdZ6jgjg.

Banda, C., 2019, 'The privatised self? A theological critique of the commodification of human identity in modern technological age in an African context professing Ubuntu', HTS Teologiese Studies/Theological Studies 75(1), a5288. https://doi. org/10.4102/hts.v75i1.5288

Banda, C. \& Senokoane, B.B., 2009, 'The interplay between the Christian sacralization of human authority and political repression in Zimbabwe', Religion \& Theology 16 207-245. https://doi.org/10.1163/102308009X12561890523636

BBC News, 2017a, Zimbabwe's Robert Mugabe resigns, ending 37-year rule, viewed 18 January 2021, from https://www.bbc.com/news/world-africa-42071488.

BBC News, 2017b, Zimbabwe's sacked Vice-President Mnangagwa flees, viewed 18 January 2021, from https://www.bbc.com/news/world-africa-41914768.

Buchanan-Clarke, S. \& Mashingaidze, S., 2020, Zimbabwe uses lockdown to undermine rule of law, viewed 20 January 2021, from https://www.businesslive.co.za/bd/ opinion/2020-07-24-zimbabwe-uses-lockdown-to-undermine-rule-of-law/.

Chikwati, E. \& Munyoro, F., 2019, Zim grateful for global support, viewed 10 December 2020, from https://www.herald.co.zw/zim-grateful-for-global-support/.

Chimininge, V., 2019, "“The voice of the people is the voice of God": A critical reflection on the use of God in promoting political legitimacy in the new dispensation in Zimbabwe', Journal of Politics and Religion 32(2), 37-59.

Chinaka, C., 2017, Zimbabwe's Mugabe says he is people's choice for 2018 election viewed 26 December 2020, from https://www.reuters.com/article/us-zimbabwemugabe-idUSKBN15YOFO].

Chingarande, D., 2019, 'We are not your puppets, ED told', The Standard, viewed 06 December 2019, from https://www.thestandard.co.zw/2020/02/02/notpuppets-ed-told/.

Dombo, S., 2014, 'Refusing to be co-opted? Church organizations and reconciliation in Zimbabwe with special reference to the Christian Alliance of Zimbabwe 2005-2013', Journal for the Study of Religion 27(2), 137-171.

Dube, B., 2020, 'Regime enablers and captured religious mandate in Zimbabwe', Verbum et Ecclesia 41(1), a2126. https://doi.org/10.4102/ve.v41i1.2126

Dzirutwe, M., 2007, Mugabe warns Catholic bishops over politics, viewed 30 August 2015, from https://www.reuters.com/article/us-zimbabwe-mugabe-bishops-idUS L0430109020070504.

Erickson, M.J., 1998, Christian theology, 2nd edn., Baker Academic, Grand Rapids, MI.

Garusa, T., 2019, 'God is the solution' says Mnangagwa, viewed 08 December 2020 from https://www.newzimbabwe.com/god-is-the-solution-says-mnangagwa.

Grudem, W.A., 1994, Systematic theology: An introduction to biblical doctrine InterVarsity Press, Leicester.

Gunda, M.R., 2015, On the public role of the Bible in Zimbabwe: Unpacking Banana's 're-writing' call for a socially and contextually relevant Biblical Studies, University of Bamberg, Bamberg.

Hadebe, N.M., 2017, 'Commodification, decolonisation and theological education in Africa: Renewed challenges for African theologians', HTS Teologiese Studies/ Theological Studies 73(3), a 4550. https://doi.org/10.4102/hts.v73i3.4550

Human Rights Watch, 2020, World report 2020: Rights trends in Zimbabwe, viewed 16 December 2020, https://www.hrw.org/world-report/2020/country-chapters/ zimbabwe.

Longman, T., III, 2006, Proverbs, Baker Academic, Grand Rapids, MI.

Machaya, P., 2019, Emmerson Mnangagwa equates self to God, says rivals Satan viewed 27 December 2020, from https://www.zimlive.com/2019/03/12/emmersonmnangagwa-equates-self-to-god-says-rivals-satan/.

Machivenyika, F., 2017a, Updated: VP Mnangagwa fired from Govt, viewed 18 January 2021, from https://www.herald.co.zw/breaking-ed-mnangagwa-fired/.

Machivenyika, F., 2017b, Zanu-PF expels Mnangagwa, viewed 18 January 2021, from https://www.herald.co.zw/zanu-pf-expels-mnangagwa/.

Machivenyika, F. \& Ziwira, E., 2020, We honour Nehanda's heroics - President, viewed 27 December 2021, from https://www.herald.co.zw/we-honour-nehandas27 December 2021

Madzimure, J., 2020, President addresses Zaoga international leaders in Harare viewed 10 December 2020, from https://www.herald.co.zw/president-toaddress-zaoga-missions/.

Magaisa, A.T., 2019, Big Saturday read: The regime and its enablers, viewed 28 December 2020, from https://bigsr.africa/bsr-the-regime-and-its-enablers-d27/.
Magaisa, A.T., 2020, BSR exclusive: Beneficiaries of the RBZ farm mechanisation scheme viewed 24 January 2021, from https://bigsr.africa/bsr-exclusive-beneficiaries-ofthe-rbz-farm-mechanisation-scheme/.

Makomborero, H., 2020, Black workers earned far better wages under lan Smith's Rhosedian government than black workers are earning under Emmerson Mnangagwa's Zimbabwe government, viewed 15 December 2020, from https:// Mnitter.com/MakomboreroH/status/1320256579275546624.

Mbofana, T.R., 2018, The voice of the people is NOT the voice of God, viewed 19 November 2020, from https://www.pambazuka.org/advocacy-campaigns/voicepeople-not-voice-god.

Methula, D.W., 2014, 'Engaging in the struggle for economic justice in the streets of the City of Tshwane', Missionalia 42(1-2), 107-119. https://doi.org/10.7832/42$1-2-50$

Mnangagwa, E.D., 2017a, In full: Emmerson Mnangagwa's plea for Mugabe to resign, viewed 08 December 2020, from https://www.timeslive.co.za/politics/2017-1121-in-full--emmerson-mnangagwas-plea-for-mugabe-to-resign/.

Mnangagwa, E.D., 2017b, President Mnangagwa's inauguration speech in full, viewed 03 May 2020, from https://www.chronicle.co.zw/president-mnangagwasinauguration-speech-in-full-2/.

Mnangagwa, E.D., 2018, President Mnangagwa's inauguration speech, viewed 08 December 2020, from https://www.sundaynews.co.zw/president-mnangagwasinauguration-speech/.

Moyo, J., 2018, \#NelsonChamisa's Prayer for Zimbabwe, viewed 22 November 2020, from https://www.youtube.com/watch?v=SvDkidf3kZk.

Ndlovu, R., 2018, Zimbabwe opposition looks to the heavens as it tries to topple Zanu $P F$, viewed 26 December 2020, from https://www.timeslive.co.za/news/
africa/2018-07-24-zimbabwe-opposition-looks-to-the-heavens-as-it-tries-totopple-zanu-pf/.

Ndore, T.E., 2019, Mnangagwa compares himself with God in heaven \& opposition with 'Satan', viewed 28 January 2021, from https://iharare.com/ watch-mnangagwa-compares-himself-with-god-in-heaven-opposition-withwatch-mn.
satan.

News24, 2008, Mugabe: It's up to God, viewed 26 December 2020, from https://www. news24.com/news24/mugabe-its-up-to-god-20080620.

News24, 2017, Full statement: 'I'm not going anywhere... Zanu-PF is not your personal property', viewed 07 December 2020, from https://www.news24.com/news24/ Africa/Zimbabwe/full-statement-im-not-going-anywhere-zanu-pf-is-not-yourpersonal-property-mnangagwa-tells-mugabe-20171108.

Ruwende, I., 2017, First family attends Xmas eve church service, viewed 10 December 2020, from https://www.herald.co.zw/first-family-attends-xmas-eve-churchservice/.

Share, F., 2018, Churches endorse ED, viewed 22 December 2020, from https://www. herald.co.zw/churches-endorse-pres-mnangagwa/.

Share, F. \& Mugabe, T., 2017, Hero's welcome for Mnangagwa...ED pledges servant leadership...Thanks the nation for support, viewed 21 November 2020, from https://www.herald.co.zw/heros-welcome-for-mnangagwa-ed-pledges-servantleadership-thanks-the-nation-for-support/.

Shumba, P., 2014, President God-given: Church, viewed 26 December 2020, from https://www.herald.co.zw/president-god-given-church/

Taringa, N., 2006, 'How environmental is African traditional religion?', Exchange 35(2), 191-214. https://doi.org/10.1163/157254306776525672

Taruvinga, M., 2020, Mnangagwa in passionate plea to God to bring end COVID-19 pandemic, viewed 13 December 2020, from https://www.newzimbabwe.com/ mnangagwa-in-passionate-plea-to-god-to-bring-end-covid-19-pandemic/.

The Herald, 2020, Govt responds to Catholic Bishops Conference claims, viewed 29 December 2020, from https://www.herald.co.zw/govt-responds-to-catholicbishops-conference-claims/.

Winter, J., 2017, Robert Mugabe: Is Zimbabwe's ex-president a hero or villain?, viewed 24 January 2020, from https://www.bbc.com/news/world-africa-23431534.

YouTube, 2018, Munangarwa Muka ubike Doro, viewed 19 May 2020, from https:// www.youtube.com/watch?v=HgSTS_9yyWY.

Zimbabwe Catholic Bishops' Conference, 2020, The March is not ended - Pastora letter of the Zimbabwe Catholic Bishops' conference on the current situation in Zimbabwe, viewed 29 December 2020, from http://kubatana.net/2020/08/14/ the-march-is-not-ended-pastoral-letter-of-the-zimbabwe-catholic-bishopsconference-on-the-current-situation-in-zimbabwe/.

Zvobgo, C.J., 2005, 'Church and state in Rhodesia: From the unilateral declaration of independence to the Pearce Commission, 1965-72', Journal of Southern African Studies 31(2), 381-402. https://doi.org/10.1080/03057070500109607 